\title{
Turin and Lingotto: resilience, forgetting and the reinvention of place
}

\section{Annalisa Colombino \& Alberto Vanolo}

To cite this article: Annalisa Colombino \& Alberto Vanolo (2016): Turin and Lingotto: resilience, forgetting and the reinvention of place, European Planning Studies, DOI: 10.1080/09654313.2016.1254598

To link to this article: http://dx.doi.org/10.1080/09654313.2016.1254598

\section{Published online: 14 Nov 2016.}

Submit your article to this journal \lceil

Q View related articles $\sqsubset$

View Crossmark data $\nearrow$ 


\title{
Turin and Lingotto: resilience, forgetting and the reinvention of place
}

\author{
Annalisa Colombino ${ }^{a}$ and Alberto Vanolo ${ }^{b}$

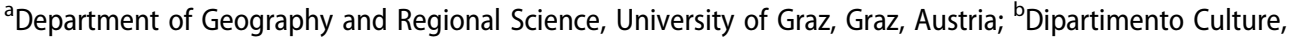 \\ Politica e Società, Università degli Studi di Torino, Torino, Italy
}

\begin{abstract}
Lingotto used to be an important industrial site and a highly symbolic space at the heart of the city of Turin, Italy. The aim of this article is to analyse the multiple trajectories, spatialities and layers of memories, meanings and practices that overlapped within and across Lingotto in the last decades, following the changing economic conditions and connected discursive paradigms associated with the evolution of the local economy since the Fordist crisis of the 1970s. The analysis shows that Lingotto may be interpreted as a mirror of Turin's resilience strategies used to cope with the economic crises that have hit the city. Furthermore, it shows how Lingotto is a highly resilient urban fragment and building. Contrary to mainstream debates about the need to conserve and stage local urban heritages, this paper offers an account of Lingotto's resilience, which highlights how forgetting the past may be a strategy for tackling the present and being resilient. The analysis of the evolution of Lingotto thus contributes to understanding urban processes that entwine with the quest for resilience in the contemporary post-industrial city, stressing the ambiguous role of the often-implicit politics of forgetting and amnesia in a framework of urban resilience.
\end{abstract}

\section{ARTICLE HISTORY}

Received 27 September 2016 Accepted 4 October 2016

\section{KEYWORDS}

Resilience; forgetting; multi-

functional spaces; cultural containers; post-Fordism; cultural economy

\section{Introduction}

In this paper, we offer an analysis of a specific building or, to be more precise, a former industrial site with several interconnected buildings: Lingotto, located in Turin, Italy. This huge industrial complex (about 250.000 sq.m.), built by FIAT car manufacturing at the beginning of the last century, has physically survived for about 100 years. Yet, it has not remained the same. Over the decades, Lingotto has been partially altered and renewed to serve different functions and host various activities. More importantly, it has changed its roles and functions along with Turin's overall urban development paths. Lingotto, in fact, has accompanied the various socio-economic phases characterizing the evolution of the city over the last century. In this sense, we will argue that Lingotto is highly resilient in sociocultural terms, being apparently capable of resisting an inevitable massive decadence by changing and adapting to evolving urban conditions and economic conjunctures. Yet, at the same time, we will point to how its very resilience is connected to 
a process entailing also the forgetting of its former role and identity, namely, through a process involving a certain degree of amnesia of its Fordist, industrial, past. Such an understanding of Lingotto's resilience troubles mainstream narratives about the importance of remembering, preserving and branding the heritages and histories of the past in the contemporary city.

The perspective informing the analysis that follows is closely connected to a traditional idea at the core of urban studies: space provides a medium that - through different, complex and multidirectional processes - fixes social processes, which researchers can explore. This is Edward Soja's (1980) conceptualization of the socio-spatial dialectic: societies create and modify urban spaces while, at the same time, social phenomena are differently shaped by the spaces in which they develop. Here, we offer an analysis of the relation between society and space which focuses on the relationship between the city of Turin as a whole (broadly understood as an urban economy that experienced, and still is experiencing, the evolution from Fordism to various and ambiguous forms of post-Fordism) and Lingotto. We will point out that Lingotto's resilience testifies, in many ways, the resilience of the city. We will show how by looking at Lingotto, it is possible to find signs, traces and spectres of the diverse strategies and development paths that have characterized Turin. Importantly, by highlighting how forgetting the past of Lingotto - rather than conserving it for branding and cultural consumption purposes - creates a space of amnesia in Turin, we will suggest that forgetting might be a practice, which may illuminate some of the dynamics involved in current and past urban resilience processes.

To offer an account that points to how the resilience of Lingotto emerges as a process made of brick-and-mortar and gradual amnesia, and to how it is possible to interpret Lingotto and its transformations as a sort of map of the trajectories of the city's development, we draw on a heterogeneous set of sources. First, we were able to access a large amount of archive sources, thanks to the kind help of the Centro Storico FIAT, a documentation centre that collected an astonishing amount of materials about the history of the company. ${ }^{1}$ More precisely, we had access to eight books and six academic papers focusing specifically on Lingotto; several internal FIAT documents (e.g. investment plans, documentation related to specific structural issues of the building); dozens of brochures about the building and events there organized; and a large collection of press reviews, including hundreds of newspaper articles about Lingotto, published since the 1980s in Italy and overseas. To build the narrative that runs through these pages, we have classified and coded the texts and images of most of the books, papers, documents and brochures according to themes and keywords. As for the newspapers articles, we have considered only the titles and, in some specific cases, we included their full texts in our analysis. Second, our study has been then complemented with ethnographic and auto-ethnographic incursions into Lingotto. Both of us of grew up in the city or in its periphery (one of us still lives and works there) and both our families have members who worked for FIAT. Lingotto is a rather familiar space for us, in our memories and also everyday experiences of Turin. Between May and July 2016, we explored the site on several occasions with the specific purpose of acquiring materials for this article. Yet, long-time memories about the place abound in our minds. Some of our memories of Lingotto have been integrated into the analysis, as sorts of 'emotional gazes'. The aim was to produce a thicker ethnographic account of the place through the mobilization of autobiographic materials, 
intended as the use of personal experiences in order to understand cultural experiences (Butz \& Besio, 2009; Ellis, 2003; Purcell, 2009). The idea at the basis of this methodology is that the introduction of personal memories and impressions does not limit the rigour of the analysis. Rather, they add 'something', and specifically the possibility of privileging the role of emotions, situated knowledge and perception (Banks, 2003; Moss, 2001). In this specific case, our personal memories have been mobilized with the aim of infiltrating some of what geographers notably call 'sense of place' into our account of Lingotto (see, among the others, Crang \& Cook, 2007; Ellis, 2003; Vannini, 2015).

The paper is structured as follows: Section 2 briefly points out that urban resilience is a contested notion and focuses on how we understand and mobilize resilience for our analysis, also by relating the concept to issues concerning memory and processes of forgetting. Section 3 provides a brief overview of the dynamics of the city of Turin over the last century by emphasizing how FIAT car manufacturing played a pivotal role in its development and reinvention after the crisis of Fordism. Section 4 offers a few hard facts about Lingotto. Section 5 represents the core of our analysis, which is followed by some brief concluding remarks on the relationship between urban resilience and forgetting.

\section{Some notes on urban resilience}

Although the concept of resilience has a long history, the application in urban studies is more recent. Specifically, during the 2000s, the idea of urban resilience has been widely mobilized in order to describe the capability of cities to recover from different kinds of stresses, including, for example, environmental disasters, changing economic conditions, lack of resources, terrorist attacks (see, for example, Cote \& Nightingale, 2013; Cooke \& Eriksson, 2012; Evans, 2011; Gunderson, 2000; MacKinnon \& Derickson, 2013; Newman, Beatley, \& Boyer, 2009; Stehr, 2006; Tidball \& Kransy, 2007; Vale \& Campanella, 2005). From a theoretical point of view, resilience is widely associated with the idea of 'elasticity', that is, the ability to absorb and accommodate perturbation without a major structural transformation of the system (Simmie \& Martin, 2010), and with the notion of adaptability, as shocks may push a system towards a different behaviour (Lazzeretti, 2013). In this sense, urban resilience is basically intended as an evolutionary concept; that is, the differential ability of 'systems' (in this case, a city and a building) to adapt to changes in competitive, market, technological, policy and related conditions that affect the evolutionary dynamics and trajectories of these systems over times (Hassink, 2010; McGlade, Murray, Baldwin, Ridgway, \& Winder, 2006; Pike, Dawley, \& Tomaney, 2010).

Recently, the concept has been widely used to interpret a number of very different phenomena shaping the city. Recent explorations comprise, for example, Cabras and Mount's (2016) analysis of the role of pubs and publicans in contributing to economic development in Ireland. In the U.K., Mehmood (2016) has focused on investigating the Transition Town movement to highlight how bottom-up, innovative and creative, initiatives are key sources for communities to tackle change. In the special issue, 'Governing for urban resilience', edited by Beilin and Wilkinson (2015), Wagenaar and Wilkinson (2015) have analysed how discourses and assumptions of social-ecological resilience shape spatial planning processes in Melbourne. In another recent special issue (Lazzeretti \& Cooke, 2015), Pasquinelli and Sjöholm (2015) have offered a multi-scalar perspective to 
investigate how artists draw on and navigate through a variety of spaces at different scales (from the intimate space of their studios, through their neighbourhoods and cities to cyberspace) and cope with the precariousness of their jobs.

What is common to most contributions in the field is the general assumption that resilience is necessarily a positive attribute, producing desirable outcomes. Although this is surely the case for a number of urban stories, it is useful to challenge this assumption by trying to consider also critical understandings and dark sides of resilience. Cooke (in press), for example, has discussed this topic within a framework linking economic crisis and arts, while MacKinnon and Derickson (2013) have stressed how intending resilience as the capability to 'resist' or to 'cope' with change may have a rather conservative meaning. This paper aims at contributing to the development of critical understandings of resilience by exploring the ambiguous relations between resilience and processes of forgetting. The analysis develops at the intersection of two geographical scales: that of the city of Turin and the scale of one of its iconic buildings, the Lingotto factory, which incorporated and reflected Turin's economic specialization - car manufacturing. We adopt a notion of resilience useful to point out, first, how a city such as Turin may cope, more or less quickly, with a series of economic crises by changing its economic basis and turn to a different economic specialization; second, to account for how a building, such as Lingotto, may be interpreted simultaneously as resilient in itself and as a mirror of urban resilience strategies. More specifically, in this paper, the resilience of Lingotto is conceptualized, from a sociocultural perspective, as the capability to change and adapt to evolving conditions and needs, for example, by changing the building's meanings and functions. As it will be argued, the Lingotto building is still here, as a sort of giant golem within the city: still there, with the same name, with the same identical façades. At the same time, it is no longer the symbolic temple of a one-company town. Lingotto has been many 'other things' over time, playing a vital role within the context of a transforming city. As it will be argued in the next sections, the transformation of Lingotto into a completely different place, hosting an array of 'post-industrial' functions, has taken form with a high degree of disconnection from its original meaning and role, which entailed a rupture in its development trajectory through the 'forgetting' of its Fordist nature and identity.

While there is a wide geographical literature on memory and spaces of memory, particularly in relation to monuments and memorials, commemoration rituals, nostalgia, material heritages, historical landscapes (for a review see Legg, 2007), relatively little has been written on the importance of forgetting in geographical terms. Specifically, Brockmeier (2002) has discussed how memory and remembering are generally associated with positive connotations, while forgetting has negative ones. In this sense, Brockmeir, as well as some contributions in cultural geography (see Hoelscher \& Alderman, 2004; Legg, 2007), has tried to challenge and deconstruct many of the binaries through which memory has traditionally been conceived, including the dichotomist opposition between memory and forgetting. In this paper, it will be argued that Lingotto is both a place of memory and forgetting, and that forgetting may be as strategically relevant as remembering. In fact, the transformations of the building have increasingly removed the industrial identity from Lingotto, by provoking the emergence of an amnesia at the core of Turin's urban texture. However, and provocatively in opposition with mainstream narratives about 
place-making and heritage development, we will argue that selective amnesia and forgetting may be, in some cases, strategic for fostering resilience.

\section{Fiat and the city: the break-up of a symbiotic relationship}

Turin is located in Northwest Italy and counts a population of nearly 900,000 inhabitants in the municipality, and 1.7 million people in the metropolitan area. ${ }^{2}$ Throughout the twentieth century, the history of Turin has been closely connected to FIAT car manufacturing (Gabert, 1964), founded by Giovanni Agnelli in 1889. Industrial growth speeded up after the First World War and, over the decades, Turin became a typical factory-town, similar to Detroit, by specializing in cars. Migrants, especially from Eastern and Southern Italy, contributed to the demographic growth of the city and FIAT's workforce. At the beginning of 1970 s, nearly $80 \%$ of industrial workers were involved in car manufacturing. FIAT managed to impose a tight control over local suppliers, including financial control, which contributed to producing a symbiotic relation between the city and the company: a 'total embedding' where the spatial, institutional and cultural developments of the city and the firm were highly interconnected (Vanolo, 2015a). Such interconnections are evident in Turin's urban fabric, which bears the traces of FIAT's responses to global economic crises.

The crisis of Fordism in the 1970s brought about an internal reorganization of FIAT and a rescaling of industrial relations. While plants were re-localized in South Italy, Eastern Europe and Latin America, Turin started to change from being 'the city' of FIAT into one node of a broader production network. Demographic growth stopped and employment in the service sector increased. The large presence of unskilled workforce and of small and medium enterprises represented problems and diseconomies orbiting around the city. The introduction of automation technologies contributed to cutting 38,000 workers between 1980 and 1982. Throughout the 1980s, small local suppliers disappeared, as they were no longer competitive or underwent processes of merging and acquisition. Turin's car manufacturing system was beginning to crumble down, a disintegration which continued during the 1990s.

Local policy-makers and foundations (e.g. Fondazione Agnelli, Ires Piemonte, Compagnia San Paolo) started to imagine alternative development paths for the city, which were less focused on the car monoculture (Giaccaria, 2010). Urban visions such as the Pianura meccatronica (i.e. the development of a vast region with economic specialization in mechanical and electronic industrial sectors) and Torino Technocity (the vision of an ICT industrial city for Turin) emphasized the quest for other manufacturing vocations. However, the industrial crisis of the end of the 1990s encouraged local stakeholders to look for other, non-manufacturing, vocations for Turin. Local agencies started working to attract firms, encourage entrepreneurialism in the most qualified service sectors (such as R\&D, ICTs and the 'new economy' in general) and organize cultural events to attract tourists. The shift towards a 'knowledge society' became in fact one of the cores of Torino Internazionale, the first strategic plan of the city, published in 2000.

In 2002, the crisis of car manufacturing was blatant as FIAT announced the closure of 18 production plants all over the world. The year after, a public policy, funded by the Piemonte Region and the Development and Cohesion Fund, ${ }^{3}$ was introduced to support local suppliers in diversifying their clients and markets. Local entrepreneurs had to learn to 
react to the hypothetical closure of FIAT. The era of the 'total embedding' of FIAT in Turin was definitely over.

A key event in shaping Turin's new economic basis was hosting the 2006 Winter Olympics. When the Games were awarded in 1998, Turin's policy-makers launched an intensive branding campaign to change the city's industrial image into a vibrant, cosmopolitan and cultural city (Vanolo, 2015b). At the same time, new infrastructures such as the metro line, new buildings designed by starchitects such as Isozaki and Fuksas were built and the local cultural offer improved. After the games, Turin's transition towards the 'cultural', 'creative' or 'knowledge' economy was widely publicized. Even the car culture was promoted in an artistic perspective: the local car museum was closed in 2007 for a radical renovation and, three years later, was rebranded as MAUTO and reopened with a suggestive staging. It is estimated that the cultural sector as a whole, in 2014 , employed about $6.6 \%$ of the workers of the province of Turin and generated about 5.9\% of local GDP.

While the 2006 Winter Olympics supported a general idea of 'centrality' of Turin in the global scenario, the 2009 agreement between FIAT and Chrysler further emphasized the international visibility of the city. FIAT is obviously no longer a 'local' company and Turin is far from being a one-company town; ultimately, in 2014, the headquarter of the FIATChrysler group has been moved to London and Amsterdam. In June 2016, the headlines of Italian newspapers started to report that 'the Lingotto' was also moving Exor - the financial company controlled by the Agnelli family - to the Netherlands. ${ }^{4}$ The Lingotto - or the Lingotto group - is sometimes used in Italian newspapers' headlines and news to refer to the businesses controlled and/or partially owned by the Agnelli family, including FIATChrysler, Exor, CNH Industrial and Juventus F.C. ${ }^{5}$ FIAT may no longer have a symbiotic relationships with Turin. Yet, the name of Lingotto is still here with us, still animating local and national socio-economic debates.

\section{Introducing Lingotto: some basic facts and figures}

The plan for building Lingotto industrial plant started to take form in 1912. FIAT car manufacturing was founded in 1899 and expanded rather quickly. The former industrial sites, spread all over the city, soon revealed to be insufficient and too disconnected. Lingotto was supposed to cluster all the manufacturing activities of the company within a single compound, in close proximity to a local railway, thus following the logics of a Fordist organization of work (Olmo, 1994).

Planned by engineer Mattè-Trucco, with the contribution of several designers and architects, Lingotto explicitly echoes the structures and technical solutions of the Ford factories in Detroit (Bigazzi, 1994). The construction site opened in 1916, the plant was inaugurated in 1923, but it was completed after several years. The inauguration celebrated Lingotto as a display of modernity, technology, efficiency and rationalism. Both the king of Italy (Vittorio Emanuele III) and Mussolini actively supported and celebrated the project with public events. The site included a building for offices, a warehouse for sorting industrial materials and the factory, which was made up of two parallel assembly lines, each about 500 metres long and developing over several floors. In 1936, the factory employed about 16,800 workers and over the years produced a number of different models of cars. Inside the building, cars took form throughout the assembly lines, starting from 
the ground to the upper floors, to end up on the roof of the building, where a race track could be used to test the vehicles.

Le Corbusier visited Lingotto and enthusiastically wrote in a note:

The FIAT factory is an advance for town planning in the new mechanized age. The freeway on the roof, for example, offers evidence of the modern technical possibilities. It is not a dream, it is a reality that certain cities, such as Geneva, Algiers, and Rio de Janeiro, could be saved from the disaster that threatened them by constructing large freeways at great height (like the FIAT track) on standard structures, allowing cities to provide housing for a large population in optimal conditions. I believe in this. I see this as the solution. Today the visit to FIAT has confirmed it for me. (Le Corbusier, 1934, p. 37, our translation)

It must be noted that, over the years, architects and policy-makers highly celebrated Lingotto for its majesty. Yet, at the same time, from the very beginning, technocrats and workers were also rather critical because they saw Lingotto as an inefficient space of production: the vertical articulation of the production process over several floors was not ideal. A few years after the inauguration, the managers complained with Giovanni Agnelli - the head of the company - about the structure of the factory, which appeared to be designed as a space for celebrating FIAT, rather than as a space of production (see Buffa \& Ortoleva, 1994; Camerana, 1985; Pozzetto, 1975). ${ }^{6}$ Just 11 years after the opening of Lingotto, in 1934, Agnelli accepted the critiques and started thinking about building a new production site. In 1939, car production stopped, as the factory was a potential target of bombings during the Second World War: destroying Lingotto was perhaps seen as a way of annihilating the entire local economy and hitting hard on the entire national economy, at least on a symbolic level. Back then, therefore, car production started to be moved to a larger industrial site, called Mirafiori, located at the margins of the city, which eventually became FIAT's main production site in Turin. After the war, Lingotto was put back into operation and it kept producing cars until 1982. Despite the many technical limits, Lingotto operated as a factory for more than 60 years.

In 1982, an international competition of ideas for the redevelopment of Lingotto took place, but all projects were rejected. In 1985, Italian archistar Renzo Piano was appointed for renewing the building (Olmo, 2004). He maintained the external façades and changed the building's internal structures to accommodate different new functions, including a fairs and exhibitions centre (operative since 1992); a congress centre and a concert hall (1994); two hotels (1995) and spaces for shops and offices. In 2002, an art gallery - the Pinacoteca Agnelli - and university classrooms (mainly, yet not exclusively, for teaching courses on automotive design) were also located in Lingotto. Today, Lingotto is also home to a shopping mall (called the [8]Gallery), a gym, a movie theatre, a dental school and several companies' offices.

Right in front of Lingotto, another industrial site has been reconverted: the Carpano vermouth factory, built in 1909 and renewed between 2005 and 2007 to host the first Eataly gourmet-food mall, which has now several brand stores all over Italy and in Japan, South Korea, Brazil, Turkey, Germany, the U.S.A. and United Arab Emirates. On the back of Lingotto, a pedestrian bridge crossing the local railway was opened in 2005, on the occasion of the 2006 Winter Olympics, to connect Lingotto with the Olympic village - currently on the pages of local and international newspapers because it has been occupied by a group of refugees and migrants, giving rise to a lively political 
debate. ${ }^{7}$ Above the bridge, a large red Olympic arch dominates the landscape, testifying the important role played by the Games in shaping local and supra-local imaginaries about Turin (cf. Vanolo, 2015b).

\section{Exploring the multiple faces of Lingotto}

Our analysis of the archive material clearly points out that Lingotto has been originally intended to be a flagship industrial project for the whole city and, more broadly, for the entire country. At the beginning of the twentieth century, Lingotto was portrayed as a highly technological and modern industrial space, testifying the greatness of Italian engineering and technology and the primacy of Turin as a modern, industrial and productive city (cf. Olmo, 1994). It is not a coincidence that important personalities of the era celebrated the opening of the factory, and that its images have been proposed, for example, by Le Corbusier in his pivotal book Towards a new architecture (1931, p. 287). Lingotto was specifically built to be a glorious symbol of the Fordist age: an entire, huge, building devoted to the logics of the assembly line, industrial work and car production (Figure 1). Since the 1920s, in fact, Lingotto has often been visited by tourists and residents including FIAT workers who, on Sundays, used to visit other departments and floors of the factory, populated, during the working days by other groups of FIAT workers (Buffa \& Ortoleva, 1994; Daprà Conti, 1984). The heritage of the building's industrial architecture is still visible today on the façades, made of long and straight walls of concrete, with large windows, which may be easily decoded as symbols and memories of an industrial past, which is no longer there.

Being born in the 1970s, we do not have a direct memory and experience of Lingotto as an industrial site. However, at home, Lingotto sometimes comes up in our family stories. For example, one of the authors remembers that one of her father's favourite stories is about his own father. The author's grandfather used to work for FIAT Aviazione (the aeronautics branch of the group) as a lattoniere (a worker specialized in metal sheet forming) for about 30 years. However, during the communist witch-hunt in the 1950s, because he was a leftist, and ratted out for being registered to the FIOM (Federazione Impiegati Operai

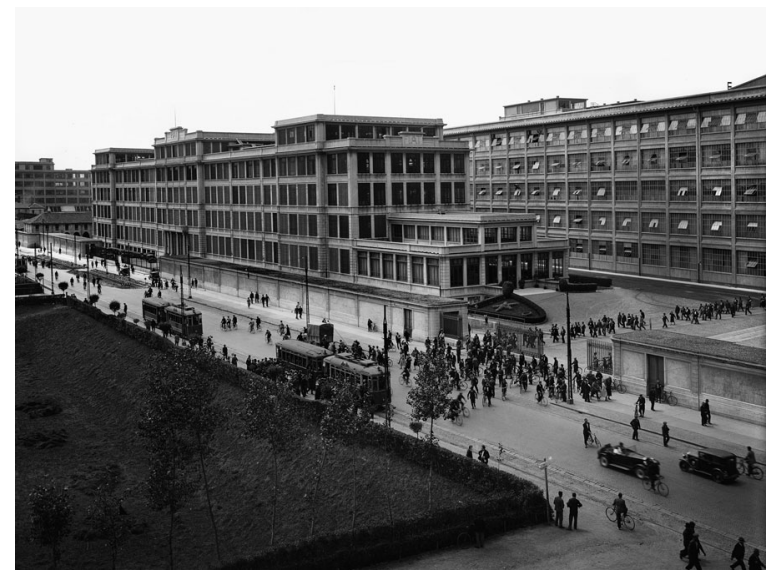

Figure 1. Lingotto in 1931. Source: courtesy of Centro Storico FIAT. 
Metallurgici, the oldest Italian union for metalworkers), the management decided to isolate her grandfather from his colleagues and relocate him to work at Lingotto for the last years of his career (1954-1959). His son, that is, the author's father, was not directly employed by FIAT, yet he used to work for the factory throughout his entire working life as a designer of special machines. He sometimes remembers Lingotto when talking about his youth. He has a vivid memory especially of the testing track on the roof, which he visited as a tourist and as a young boy with a passion for speed and cars. With a vein of nostalgia and sadness, he sometimes recollects Lingotto as an industrial plant, where he used to work on some occasions between 1975 and 1980, in a period in which the factory was close to its dismissal.

The other author associates the memory of Lingotto during his childhood to the imaginary of an 'empty space': it was an empty building lacking specific functions, with just small, specific, spaces still used for occasional public events. One of his first memories concerning the place dates back to an event somewhere in between the end of 1970s and the beginning of the 1980s: at that time, the author was a young boy, possibly five or six years old, and he remembers that he has been in Lingotto, right before Christmas, to receive the annual present from FIAT (i.e. a starship toy). This memory points to one example of how FIAT has long been much more than just a factory for the city: the sons and daughters of FIAT workers were entitled to receive the annual Christmas present, usually a very good toy. There were cues to register and get the tickets, to be shown at a large desk in order to receive the present, while music and shows were performed for the 'FIAT children'. Probably, these memories are among the last ones of a Fordist era that was going to collapse and, arguably, already collapsed at that time. Wildcat strikes started to gain momentum in the city since the early 1970s (Pizzolato, 2013), testifying the progressive crisis of the social pact binding FIAT and the city. In 1982, car production definitely stopped in Lingotto.

For more than a decade, both the city and Lingotto lived in a sort of limbo. The closing of the factory had had to be elaborated, interpreted and filled with meaning, very much like a collective trauma, and it is precisely in this sense that memory and forgetting have had to be negotiated, contested, substantiated and particularized over the years. In this framework, while some observers were keen to support the importance of memory by interpreting the 'old' factory as a piece of 'antiquity' and, hence, as a rare object of which to take care, many others considered Lingotto an obsolescent space, as a useless 'skeleton of giant dinosaur' - to quote a metaphor that journalists often used in their headlines in the 1980s (Buffa \& Ortoleva, 1994). Debates over the collapse of the working class, the 'third industrial revolution', deindustrialization and the perils of the spreading of a rust belt overlapped with debates about the transformations of Lingotto, producing tensions between narratives of preservation and transformation.

During the 1980s, Turin started thinking and discussing about possible, alternative development paths, without stepping into any specific strategy (Vanolo, 2015a). It was clear that the city had to move in a different direction, namely, move away from the monoculture of FIAT and car manufacturing in general. Yet, it took almost two decades - with FIAT's fluctuating economic performances - before alternative strategies and visions were formalized and institutionalized. Perhaps, the first official strategy has been to try to support Turin's transformation into a 'technopole', specialized in high-technology and R\&D activities (as many other Fordist cities in Europe and elsewhere; cf. Castells \& 
Hall, 1994). The physical structure of Lingotto clearly reflected the years of 'lethargy' - that is, the time needed to elaborate the trauma of deindustrialization - which accompanied the formulation of that urban strategy for Turin. The 1982 international call for ideas did not have any real outcomes, exception made for the production of projects, which were then displayed in a local exhibition (cf. Zardini, 1984). In 1983, Il Sole 24 Ore, the main Italian economic newspaper, carried the headline 'There is a Lingotto after the factory', thus suggesting the will of giving the factory an 'afterlife'; that is, a new life after its industrial dismissal. ${ }^{8}$ Local debates were animated by the emergence of several ideas for the potential reuse of the building (science park, convention centre, cultural centre, an Italian Beaubourg, etc.), all in line with the promises and needs of a 'post-industrial' society. No one, not even the representatives of the Italian Communist Party, supported the idea of keeping industrial activities alive in Lingotto. As mentioned before, in 1985, Renzo Piano was appointed as the architect in charge of the project for the redevelopment of the site, but it took almost 15 years for the project to be implemented (Olmo, 2004). From the beginning of the 1980s to the second half of the 1990s, Lingotto stood still, empty, in all its majesty and uselessness. At the beginning of the 1990s, when one of the authors was about 18 years old, in the craziness of his youth, he decided, with a friend, to climb over the walls of the factory during the night and go inside the abandoned building. There were traces of some initial redeveloping works taking place. Yet, the skeleton of the 'dinosaur' was entirely visible, empty and impressive. The building was huge and totally empty. To the young boy, it looked like the dead body of a giant whale, but the whale was not yet really dead, in a metaphorical sense.

The initial redevelopment of Lingotto can be interpreted within the framework of the global transformations in the urban politics characterizing the post-Fordist age (Amin, 1994). Turin, as many other industrial cities, was going to become primarily a site of consumption, rather than production (cf. Hannigan, 1998; Harvey, 1990; Knox, 1991). Lingotto, described in magazines and newspapers as the 'major Italian redevelopment site', ${ }^{9}$ was going to be turned into a 'multifunctional space' devoted to 'culture, technology and leisure'; in practice, a shopping mall with office spaces on the upper floors. The place has been quickly crowded with several shops, together with restaurants and other services.

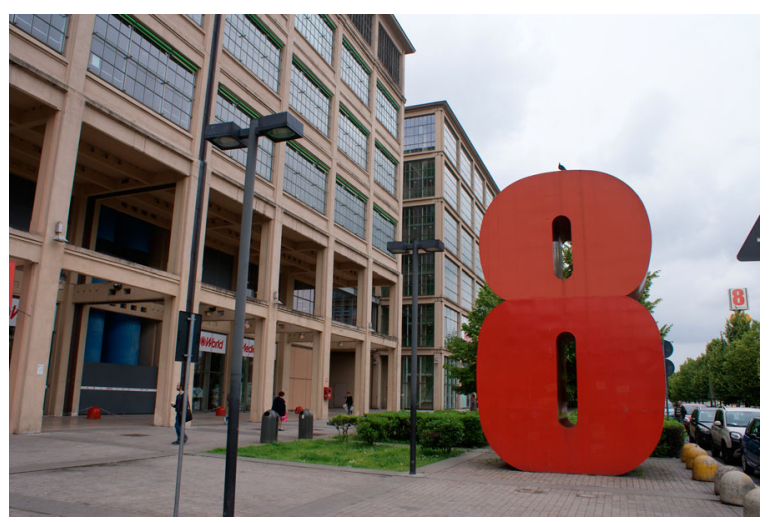

Figure 2. The '8 gallery' logo in front of the entrance. Source: photo by the authors, June 2016. 
It has also been branded as a shopping mall, with the logo [8], where eight is pronounced in Italian 'otto', as in Lingotto (see Figure 2).

The redevelopment of Lingotto as a (sort of) shopping mall may be interpreted in relation to a general and deliberate act of forgetting of the industrial heritage and identity characterizing the city, and the attempt at translating Turin into something radically different from an industrial city. The crisis of FIAT took momentum during the 1980s and reached the apex at beginning of the 1990s (Whitford \& Enrietti, 2005), strongly nurturing the idea of the industrial sphere as something negative, dirt, undesired. A very limited number of observers wished to keep Lingotto as a space of memory, or a kind of museum of the past, while most of local stakeholders were willing to welcome changes, even unrealistic ones. Valentino Castellani, mayor of the city from 1993 to 2001, described the redevelopment of Lingotto as a sign of the will of both the municipality and local enterprises to 'turn the page'. ${ }^{10}$ After the redevelopment of Lingotto, almost nothing suggested that there was a factory inside the building. One of the few inner elements that has been kept is the helical access ramp, which allowed cars to reach the test track on the roof, and which can now be used by customers to access the upper floors (Figure 3), while a carousel has been now located in the centre of the ground floor. In front of Lingotto, a small industrial village, made up of four and five storehouses (typical examples of industrial architecture of the beginning of the twentieth century) that used to be home to FIAT workers, has been purposely hindered from the view from Lingotto by planting a scenario of trees. In synthesis, the entire building has been aesthetically, discursively and functionally disembedded from the industrial sphere in order to 'produce an authentic piece of city. ${ }^{11}$ Neon lights, an helicopter landing field on the roof and a brand new 'glass bubble' on the top of Lingotto (an exclusive meeting room with panoramic view hosting a maximum of 25 people) may be easily decoded as traces of the aspirations and desires of Turin to play a role in the postmodern urban world and be placed on the map of global urban competition.

The conversion of Lingotto into a temple of consumption has not been an easy task, also because the building has been evidently constructed with different rationales in mind. Walking through the former factory, it is easy to spot dead corridors, useless doors and stairs, blind corners and other dysfunctional spaces, which cannot be used to

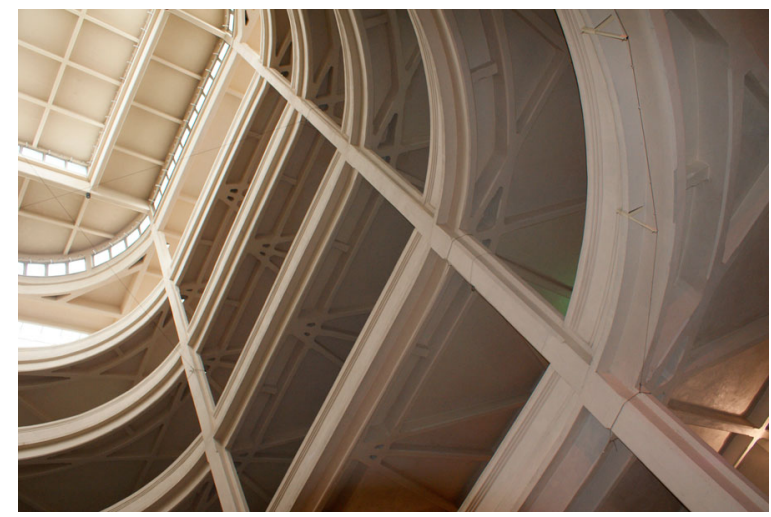

Figure 3. The helical access ramp. Source: photo by the authors, 2016. 


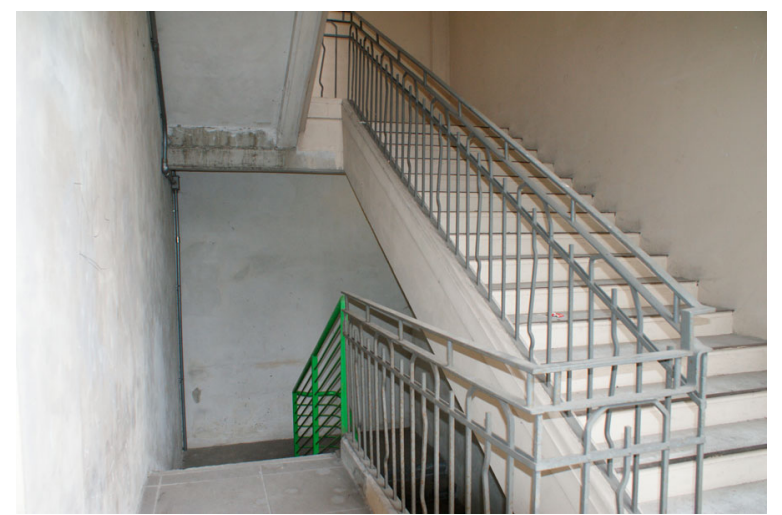

Figure 4. Marginal spaces. Source: photo by the authors, 2016.

host any commercial activity and, hence, they stay empty, often unnoticed (see Figure 4). During fieldwork, we purposely tried to open anonymous, closed, doors: some of them were locked, yet other could open under the pressure of our hands, allowing us to see dark halls, abandoned stairs and other 'marginal' spaces. Being a huge industrial building, there are still a lot of these interstitial spaces, which can be interpreted as the material spatial manifestation of the fractures characterizing the disjuncture with the original meaning and development path of the building. Another visible aspect is the presence of relevant differences in terms of both accessibility and value between the various areas within the complex: the more one moves towards the margins of the building, the more one finds cheap stores and low-value activities. Towards the end of Lingotto, for example, there is a large space with games for children, as if it were an urban playground: this area may be important in terms of social functions, but it is evidently marginal from an economic perspective, as it is usually crowded by mass-consumption stores and empty shops as well (Figure 5).

These examples serve to point out that the process of translation of Lingotto from a place of production to a place of consumption has been largely uneven, reflecting metaphorically and materially the adhesion to a neoliberal culture. While spaces on the

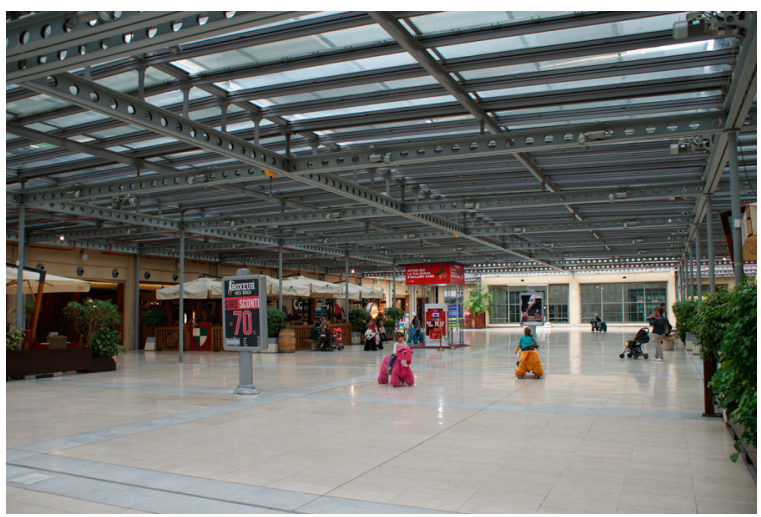

Figure 5. A low-density use area. Source: photo by the authors, 2016. 


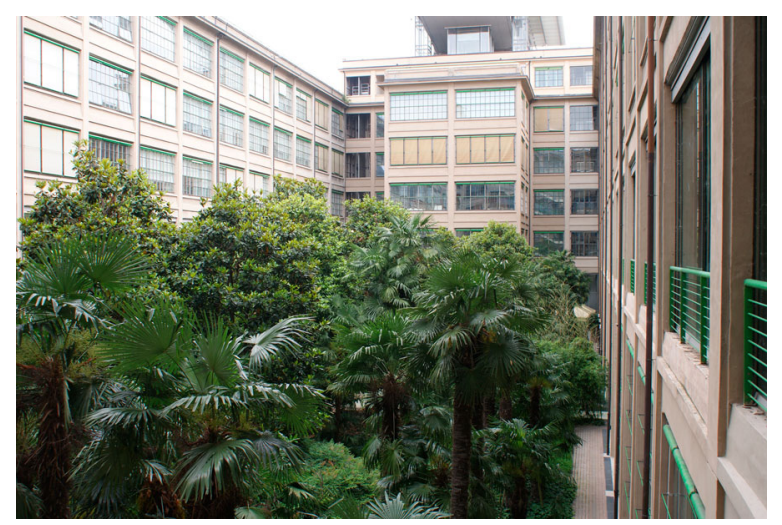

Figure 6. The exclusive tropical garden. Source: photo by the authors, 2016.

margins lie down as hidden ruins, concealed by closed doors and plasterboard walls, some other parts of the building may be accessed only by the richest segment of the consumers. This is the case of the 'tropical garden': a green area that has been realized in an inner courtyard (Figure 6). The area is accessible only to the customers of a fancy hotel/restaurant. Ordinary mall customers may only see it through the windows of an upper floor. By pushing a closed door, we easily accessed the garden, but then we have been pushed away by a member of the security.

As mentioned before, since the publication of the first strategic plan of the city in 1999, Turin progressively followed the path of the 'knowledge economy' and 'creative city' strategies (Pinson, 2002; Vanolo, 2015a, 2015b). It is interesting to read the signs of these strategies in the material configuration of Lingotto. The most evident sign is the presence of an art gallery within the building, opened in 2002. Its bookshop is on the first floor, close to 'ordinary' shops, but with an elevator, it is possible to reach the upper floor, where the gallery is located, mostly made up of paintings belonging to the Agnelli family. The Pinacoteca Agnelli is the place of high culture in the mall, infusing a sense of cultural capital to the entire building and, perhaps, to the entire shopping experience. It reflects the new 'spirit of capitalism', where shopping is less stigmatized if imbued with a cultural content and if it looks different from consumerism (McGuigan, 2009).

The more recent element testifying this new spirit of capitalism is epitomized by Eataly, the now internationally famous brand of gourmet food. Today, in fact, high-quality, local, food products - for example, wine, chocolate and ice cream - are becoming highly popular, particularly for wealthy foreign consumers and tourists, and many local companies are expanding, thanks to the export of their goods in Italy and overseas. Generally speaking, food production and retail are perceived as a meaningful pillar for the economic recovery of the city, in a framework of diffuse industrial crisis (Vanolo, 2015b). In this framework, the old Carpano factory, which now hosts Eataly, has been converted as a highly symbolic cultural space related to the consumption of food. It is not just a place where to buy and eat food, but also to have a cultural experience of food: Eataly in Turin, as well as in its other branches, is in fact imbued with discourses, images and experiences that aim to incorporate in its consumers and visitors a culturally deep and cosmopolitan (and arguably expensive) experience of drinking and eating 'earthy delights' - genuine, local, 


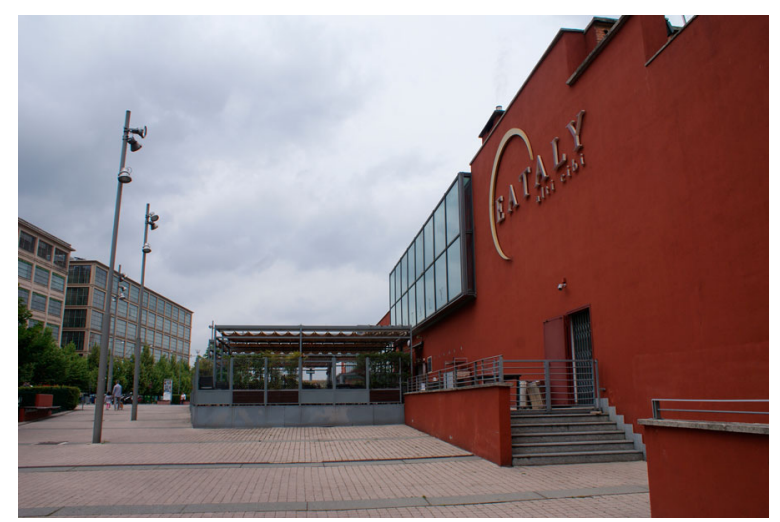

Figure 7. Eataly and Lingotto. Source: photo by the authors, 2016.

artisanal food (Figure 7). The food mall also contains the museum of the Carpano factory and has been also enriched with arts as, for example, the installation 'Mare Mater', by Anna Paola Cibin, located 'between the fruit and vegetables and the fish sections'. ${ }^{12}$

Finally, walking through Lingotto, it is impossible to forget that the history of the development strategies of Turin during the last decade is deeply connected to the hosting of the 2006 Winter Olympic Games. The giant Olympic Arch standing over the pedestrian bridge is a highly visible remainder of the Games (Figure 8). Walking along the 400metre bridge, over the local railway, one can have a view on Lingotto and fully perceive the huge size of the building and its many faces. Silence outside, on the bridge, and noise inside. Few people outside, and crowds inside. Consumption inside (and production, a long time ago), and mere walking outside. The bridge metaphorically connects Lingotto with the 'ordinary city' (a residential area with relatively low real estate value); or, walking in the opposite direction, walking through the bridge and passing the arch may be seen as a sort of rite of passage allowing the entering into the 'new' urban space of consumption, of high-quality food, culture and sport - all keywords of the contemporary development strategies of Turin.

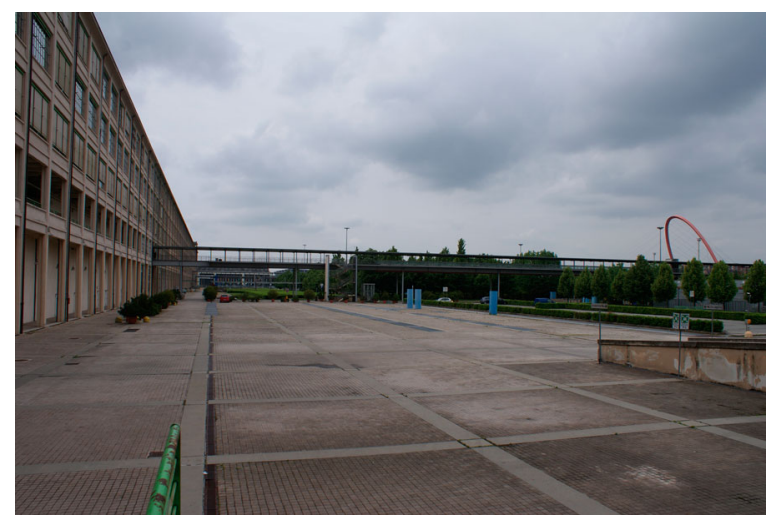

Figure 8. Lingotto, the pedestrian bridge and the Olympic arch. Source: photo by the authors, 2016. 
It is not the aim of this article to discuss whether these urban development strategies are effective and just, or not. The point is rather that Lingotto mirrors all these strategies. In fact, the place has been more and more used and branded as a container for cultural events. For example, hosting the international festival for electronic music 'Movement' since 2006, allows thousands of young adults to party in the former FIAT factory. Or, in relation to art, Lingotto hosts the international event 'Artissima', which since 1994 focuses on the contemporary art market. What, however, strikes when walking through Lingotto is the high fragmentation of all these discourses: signs (and stereotypes) related to ideas of 'high culture' and 'cultural capital', such as gourmet restaurants, art books and contemporary art paintings, stand side by side with signs that may be easily associated with 'low culture' and 'mass consumerism', such as cheap shops, electronic gambling machines and 'fake' ethnic restaurants. Of course, the point of this comment is not to provide a moral evaluation of the phenomena, but just to testify how the lack of a well-defined identity for the place, together with the lack of a well-defined development strategy for the building - and arguably for the city - developed into the production of a confused space driven by the logics of profitability and market segmentation. There is a space for consumption for (almost) everyone in the former space of production of Lingotto, demonstrating the high versatility of the building or, seen in a different perspective, the high ductility of consumerism and neoliberalism in shaping urban spaces and supporting the removal and forgetting of old, undesired, phantoms of the industrial past.

\section{Concluding remarks}

Our account of Lingotto allows us to develop some reflections on the concept of resilience. The characteristic of the analysis proposed in this paper is to try to situate resilience at the crossroad of two geographical scales: the scale of the building and that of the city. Turin is a city that proved remarkable levels of resilience in translating from Fordism to different economic specializations: the city is surely experiencing the economic crisis, but several different economic sectors are also developing in relation to, for example, tourism and culture (cf. Vanolo, 2015a, 2015b). At the same time, Lingotto apparently proved to be a highly resilient building, being still used, crowded with people and economically active, after a century of life, by completely changing its functions and roles within the city. Particularly, Lingotto proved to be a highly flexible space under the logics of late capitalism, by transforming from a space of work and production (a factory) into a space of consumption (a shopping mall and exhibition centre) and, to some degrees, more recently, also as a space of cultural consumption. As discussed in the paper, these transformations mirrored wider development strategies that took form in the city, in its transition from Fordism to the heterogeneous phases and strategies characterizing the so-called post-Fordism.

However, a more critical reading of the concept of resilience may allow the questioning of the assumption that Lingotto 'is still there'. Certainly, the walls and the external façades are still there, and certainly, the name of the place is still that of a century ago, but all the rest, and particularly the industrial identity and heritage, has disappeared for most of the users of the place, and in this sense, Lingotto may be imagined as a controversial case of space of limited memory and abundant forgetting. From a sociocultural perspective, Lingotto has been metaphorically demolished and rebuilt, in order to realign to the new logics 
of late capitalism. The fact that the façades are still the same may be of great interest for a designer or an architect, but it has little meaning seen in a sociocultural perspective, because those façades have arguably no meaning and reflect no memory for the ordinary, contemporary, consumers living and experiencing that place.

We once stepped into the Pinacoteca Agnelli's bookstore asking for books about the history of the building and for someone in charge of Lingotto's public relations. However, there was nothing like that. We just received a small brochure with some old photos of the building. In a sociocultural perspective, the case of Lingotto emphasizes how the concept of resilience is linked with complex and non-linear relations with ideas of memory, identity and sense of place (cf. Massey, 1993). On the one hand, places may prove to be resilient in changing with a line of continuity, which means changing while preserving identity and sense of place. However, on the other hand, places are always changing and, by definition, they are always in the process of becoming. In this sense, a place may remain apparently the same, revealing continuity, but it may completely change its meaning over time, ultimately becoming 'something else' by erasing, negotiating or subverting collective memories. In the case of Lingotto, the place has somehow remained the same from some perspectives (e.g. its material configuration), but it has become something else under other perspectives (e.g. in terms of functions). Lingotto has been, first, abandoned (thus becoming an empty factory) and, then, reinvented as a shopping mall, a cultural container (of the painting of the Pinacoteca Agnelli, of classic and electronic music events), a medical centre, an area for international fairs and exhibitions, a site for the rebranding of Turin as a 'city of sport' and, importantly, thanks to the adjacent food mall Eataly, as a node nourishing Turin and Piedmont's gastronomic scene. Some of these functions and identities have faded away with time, some of them are still persisting, and some other will probably emerge in the future. These considerations do not aim to support nostalgic and conservative visions of a sense of place for Lingotto. Rather, they want to suggest that perhaps it is not always 'good' to preserve the memories of places (cf. Brockmeier, 2002; Legg, 2007), at least in the case of Lingotto's industrial identity. If, on the one hand, the hysterical proliferation of functions and vocations described in this paper has partly produced a space deprived of history and lacking a precise identity and a well-defined symbolic meaning (in order to accommodate whatever urban function may be economically profitable), on the other hand, Lingotto may be interpreted as a resilient space in Turin. Lingotto, in fact, has essentially survived across different trends, urban cultural frameworks and economic phases with very limited physical transformations: the same old industrial building has been adapted to very different urban needs, vocations and projects, thus mirroring the ongoing transformations of the city. This survival and resilience have also been performed through the nearly complete forgetting of Lingotto's past economic role and industrial identity. In the case of Lingotto, it appears that forgetting and resilience closely entail each other. Maybe, the ability to forget may be intended as a trait of the resilience of the city, because - to use a metaphor - forgetting may definitely be a useful survival strategy.

\section{Notes}

1. http://www.fcagroup.com/en-us/group/history/pages/centro_storico.aspx (last accessed on 13 June 2016). 
2. Data source (if an alternative source is not explicitly mentioned) is always Piemonte in Cifre 2015; http://www.piemonteincifre.it (last accessed on 20 August 2016).

3. Project From concept to car (Whitford \& Enrietti, 2005); see http://www.fromconcepttocar. com (accessed on 16 August 2016).

4. Griseri (2016).

5. See e.g. 'Marchionne, il manager che ha fatto del Lingotto un gruppo globale', Adnkronos online, 10 September 2014; Greco $(2015,2016)$.

6. See also 'Bello e superato', Il Mondo, 23-30 May 1994, pp. 81-82.

7. See, for example, Provost and Lai (2016).

8. Bosio (1983). See also Buffa and Ortoleva (1994).

9. Stefanoni (1994). The article affirms that 'when the works will be over, [the Lingotto] will be one of the most prestigious multi-functional centres of the world' (p. 60).

10. Quoted in Stefanoni (1994).

11. This sentence, attributed to Renzo Piano, is quoted in the newspaper article by Minucci (2012). Authors' translation.

12. http://www.eataly.net/it_it/negozi/torino-lingotto/archivio-torino-lingotto/mare-materexpo-2015/ (last accessed 3 June 2016, authors' translation).

\section{Disclosure statement}

No potential conflict of interest was reported by the authors.

\section{References}

Amin, A. (1994). Post-Fordism: Models, fantasies and phantoms of transition. In A. Amin (Ed.), Post-Fordism. A reader (pp. 1-39). Oxford: Blackwell.

Banks, A. (2003). Autobiography and cultural geography. Using personal experience to form research. In A. Blunt, P. Gruffudd, J. May, M. Ogborn, \& P. Pinder (Eds.), Cultural geography in practice (pp. 88-90). London: Hodder.

Beilin, R., \& Wilkinson, C. (2015). Introduction: Governing for urban resilience. Urban Studies, 52, 1205-1217. doi:10.1177/0042098015574955

Bigazzi, D. (1994). Strutture della produzione: il Lingotto, l'America, l'Europa. In C. Olmo (Ed.), Il Lingotto 1915-1939. L'architettura, l'immagine, il lavoro (pp. 281-336). Torino: Allemandi.

Bosio, R. (1983, February 11). C’è un Lingotto oltre la fabbrica. Il Sole 24 Ore.

Brockmeier, J. (2002). Remembering and forgetting: Narrative as cultural memory. Culture \& Psychology, 8, 15-43. doi:10.1177/1354067X0281002

Buffa, C., \& Ortoleva, P. (1994). Lingotto. Luogo. Simbolo. In C. Olmo (Ed.), Il Lingotto 1915-1939. L'architettura, l'immagine, il lavoro (pp. 151-192). Torino: Allemandi.

Butz, D., \& Besio, K. (2009). Autoethnography. Geography Compass, 3, 1660-1674. doi:10.1111/j. 1749-8198.2009.00279.x

Cabras, I., \& Mount, M. (2016). Economic development, entrepreneurial embeddedness and resilience: The case of pubs in rural Ireland. European Planning Studies, 24, 254-276. doi:10.1080/ 09654313.2015.1074163

Camerana, O. (1985). L'enigma del cavalier Agnelli. Milano: Serra e Riva.

Castells, M., \& Hall, P. (1994). Technopoles of the world. London: Routledge.

Cooke, P. (in press). Resilience in ruins: The idea of the "arrested dialectic" in art after resilience's failures.

Cooke, P., \& Eriksson, A. (2012). Resilience, innovative 'white spaces' and cluster platforms as a response to globalisation shocks. In P. Cooke, M. D. Parrilli, \& J. L. Curbelo (Eds.), Innovation, global change and territorial resilience (pp. 43-70). Cheltenham: Elgar.

Cote, M., \& Nightingale, A. J. (2013). Resilience thinking meets social theory: Situating social change in socio-ecological systems (SES) research. Progress in Human Geography, 36, 475489. doi:10.1177/0309132511425708 
Crang M., \& Cook, I. (2007). Doing ethnographies. London: Sage.

Daprà Conti, M. (1984). Visite al Lingotto. Torino: Celid.

Ellis, C. (2003). The ethnographic I. A methodological novel about autoethnography. Walnut Creek, CA: Altamira.

Evans, J. P. (2011). Resilience, ecology and adaptation in the experimental city. Transactions of the Institute of British Geographers, 36, 223-237. doi:10.1111/j.1475-5661.2010.00420.x

Gabert, G. (1964). Turin ville industrielle. Paris: PUF.

Giaccaria, P. (2010). La FIAT e Torino: Lavoro, relazioni industriali e immagini della città operaia. In M. Santangelo \& A. Vanolo (Eds.), Di capitale importanza. Immagini e trasformazioni urbane di Torino (pp. 57-73). Roma: Carocci.

Greco, F. (2015, July 8). Al Lingotto contratto per 85mila. Sole24Ore online, Retrieved November 4, 2016, from http://www.ilsole24ore.com/art/impresa-e-territori/2015-07-08/al-lingottocontratto-85mila-063803.shtml?uuid=ACDqiqN.

Greco, F. (2016, March 17). Marchionne: entro il 2018 piena occupazione. Sole24Ore online. Retrieved August 12, 2016, from http://www.ilsole24ore.com/art/impresa-e-territori/2016-0317/marchionne-entro-2018-piena-occupazione-063350.shtml?uuid=ACRGfjpC.

Griseri, P. (2016, July 25). Gli Agnelli lasciano l'Italia: Exor emigra in Olanda. La Repubblica online. Retrieved August 14, 2016, from http://www.repubblica.it/economia/finanza/2016/07/25/news/ exor_italia-144794214/.

Gunderson, L. H. (2000). Ecological resilience - In theory and application. Annual Review of Ecology and Systematics, 31, 425-439. doi:10.1146/annurev.ecolsys.31.1.425

Hannigan J. (1998). Fantasy city: Pleasure and profit in the postmodern metropolis. New York, NY: Routledge.

Harvey, D. (1990). Between space and time: Reflections on the geographical imagination. Annals of the Association of American Geographers, 80, 418-434. doi:10.1111/j.1467-8306.1990.tb00305.x

Hassink, R. (2010). Regional resilience: A promising concept to explain differences in regional economic adaptability? Cambridge Journal of Regions, Economy and Society, 3, 45-58. doi:10. 1093/cjres/rsp033

Hoelscher, S., \& Alderman, D. H. (2004). Memory and place: Geographies of a critical relationship. Social \& Cultural Geography, 5, 347-355. doi:10.1080/1464936042000252769

Knox, P. L. (1991). The restless urban landscape: Economic and sociocultural change and the transformation of metropolitan Washington, DC. Annals of the Association of American Geographers, 81, 181-209. doi:10.1111/j.1467-8306.1991.tb01686.x

Lazzeretti, L. (2013). The remarkable resilience of cities of art. The challenge of a new renaissance in Florence. In P. Cooke (Ed.), Re-framing regional development: Evolution, innovation and transition (pp. 256-273). London: Routledge.

Lazzeretti, L., \& Cooke, P. (2015). Introduction to the special issue 'the resilient city'. City, Culture and Society, 6, 47-49. doi:10.1016/j.ccs.2015.05.001

Le Corbusier. (1931). Towards a new architecture. London: J. Rodker.

Le Corbusier. (1934). Le Corbusier a Torino. Quadrante, 14, 37.

Legg, S. (2007). Reviewing geographies of memory/forgetting. Environment and Planning A, 39, 456-466. doi:10.1068/a38170

MacKinnon, D., \& Derickson, K. D. (2013). From resilience to resourcefulness. A critique of resilience policy and activism. Progress in Human Geography, 37, 253-270. doi:10.1177/ 0309132512454775

Massey, D. (1993). Power-geometry and a progressive sense of place. In J. Bird, B. Curtis, T. Putnam, G. Robertson, \& L. Tickner (Eds.), Mapping the futures. Local cultures, global change (pp. 59-69). London: Routledge.

McGlade, J., Murray, R., Baldwin, J., Ridgway, K., \& Winder, B (2006). Industrial resilience and decline: A co-evolutionary framework. In E. Garnsey \& J. McGlade (Eds.), Complexity and coevolution: Continuity and change in socio-economic systems (pp. 147-176). Cheltenham: Edward Elgar.

McGuigan, J. (2009). Cool capitalism. London: Pluto Press. 
Mehmood, A. (2016). Of resilient places: Planning for urban resilience. European Planning Studies, 24(2), 407-419. doi:10.1080/09654313.2015.1082980.

Minucci, E. (2012, September 20). Da Le Corbusier a Piano ha sedotto i grandi dell'architettura. La Stampa.

Moss, P. (2001). Engaging autobiography. In P. Moss (Ed.), Placing autobiography in geography (pp. 188-198). Syracuse, NY: Syracuse University Press.

Newman, P., Beatley, T., \& Boyer, H. (2009). Resilient cities. Responding to peak oil and climate change. Washington, DC: Island Press.

Olmo, C. (1994). Un teatro di ombre. In C. Olmo (Ed.), Il Lingotto 1915-1939. L'architettura, l'immagine, il lavoro (pp. 9-42). Torino: Allemandi.

Olmo, C. (2004). Le metafore e il cantiere. Lingotto 1982-2003. Torino: Allemandi.

Pasquinelli, C., \& Sjöholm, J. (2015). Art and resilience: The spatial practices of making a resilient artistic career in London. City, Culture and Society, 6, 75-81. doi:10.1016/j.ccs.2015.04.001

Pike, A., Dawley, S., \& Tomaney, J. (2010). Resilience, adaptation and adaptability. Cambridge Journal of Regions, Economy and Society, 3, 59-70. doi:10.1093/cjres/rsq001

Pinson, G. (2002). Political government and governance: Strategic planning and the reshaping of political capacity in Turin. International Journal of Urban and Regional Research, 26, 477493. doi:10.1111/1468-2427.00394

Pizzolato, N. (2013). Challenging global capitalism: Labor migration, radical struggle, and urban change in Detroit and Turin. New York, NY: Palgrave MacMillan.

Pozzetto, M. (1975). La FIAT Lingotto. Un'architettura torinese d'avanguardia. Torino: Centro Studi Piemontesi.

Provost, C., \& Lai, S. (2016, March 2). Occupy Turin: Refugees find a home in Italy's abandoned Olympic Village. The Guardian. Retrieved August 13, 2016, from http://www.theguardian. com/cities/2016/mar/02/turin-refugees-italy-abandoned-olympic-village

Purcell, M. (2009). Autobiography. In R. Kitchin \& N. Thrift (Eds.), International encyclopedia of human geography (pp. 23-239). Amsterdam: Elsevier.

Simmie, J., \& Martin, R. (2010). The economic resilience of regions: Towards an evolutionary approach. Cambridge Journal of Regions, Economy and Society, 3, 27-43. doi:10.1093/cjres/ rsp029

Soja, E. W. (1980). The socio-spatial dialectic. Annals of the Association of American Geographers, 70, 207-225. doi:10.1111/j.1467-8306.1980.tb01308.x

Stefanoni, F. (1994, May 23-30). Scommesa sul futuro. Il Mondo, pp. 60-70.

Stehr, S. D. (2006). The political economy of urban disaster assistance. Urban Affairs Review, 41, 492-500. doi:10.1177/1078087405284887

Tidball, K. G., \& Kransy, M. E. (2007). From risk to resilience: What role for community greening and civil ecology in cities? In A. E. J. Wals (Ed.), Social learning. Towards a sustainable world (pp. 149-164). Wageningen: Wageningen Academic.

Vale, L. J., \& Campanella, T. J. (2005). The resilient city. How modern cities recover from disaster. Oxford: Oxford University Press.

Vannini P. (2015). Non-representational ethnography: New ways of animating lifeworlds. Cultural Geographies, 22, 317-327. doi:10.1177/1474474014555657

Vanolo A. (2015a). The Fordist and the creative city: Evolution and resilience in Turin, Italy. City, Culture and Society, 6, 69-74. doi:10.1016/j.ccs.2015.01.003

Vanolo A. (2015b). The image of the creative city, eight years later: Turin, urban branding and the economic crisis taboo. Cities, 46, 1-7. doi:10.1016/j.cities.2015.04.004

Wagenaar, H., \& Wilkinson, C. (2015). Enacting resilience: A performative account of governing for urban resilience. Urban Studies, 52, 1265-1284. doi:10.1177/0042098013505655

Whitford, J., \& Enrietti, A. (2005). Surviving the fall of a king. The regional institutional implications of crisis at FIAT Auto. International Journal of Urban and Regional Research, 29, 771795. doi:10.1111/j.1468-2427.2005.00621.x

Zardini, M. (1984). Venti idee per il Lingotto. Casabella, 502, pp. 16-17. 